\title{
Lycium barbarum polysaccharide arbitrates palmitate-induced apoptosis in MC3T3-E1 cells through decreasing the activation of ERS-mediated apoptosis pathway
}

\author{
LEI JING and XUE-WEN JIA
}

Department of Orthopaedics, Ningbo First Hospital, Ningbo, Zhejiang 315000, P.R. China

Received July 4, 2017; Accepted November 3, 2017

DOI: $10.3892 / \mathrm{mmr} .2017 .8128$

\begin{abstract}
Palmitate (PA) has been identified to induce cell apoptosis in osteoblasts. The c-Jun NH2-teminal kinase (JNK) signaling pathway and endoplasmic reticulum stress (ERS) were found to be important contributors. Therefore, natural or synthetic agents may antagonize PA-induced apoptosis in osteoblasts, and demonstrate the potential application to reverse osteoporosis. The present study demonstrated that the Lycium barbarum polysaccharide (LBP) is as a major active ingredient of Lycium barbarum and that it can reduce the fatty acid toxicity of PA. Furthermore, this study attempted to elucidate the underlying molecular mechanisms of LBP. Firstly, it was demonstrated via a Cell Counting Kit-8 assay, that LBP could significantly increase the viability of MC3T3-E1 cells in a dose-dependent manner. Flow cytometric analysis indicated that LBP inhibits PA-induced apoptosis in osteoblastic cells. Reverse transcription-quantitative polymerase chain reaction and western blotting results showed that the expression levels of glucose-regulated protein 78, C/EBP homologous protein and cysteinyl asparate specific proteinase-3/-9/-12, were increased in MC3T3-E1 cells following PA treatment. The treatment of the cells with PA resulted in an activation of the ERS and the JNK signaling pathway. These pathways were effectively suppressed by co-incubation with LBP. Taken together, PA may cause ERS, in cell apoptosis, and it may further activate the JNK signaling pathway. LBP reversed PA-induced apoptosis in MC3T3-E1 cells through inhibition of the activation of the ERS-mediated JNK signaling pathway.
\end{abstract}

\section{Introduction}

Decreas bone mineral content and increase in bone fragility that may cause structural variations in bone tissue are typical

Correspondence to: Dr Xue-Wen Jia, Department of Orthopaedics, Ningbo First Hospital, 59 Liuting Road, Ningbo, Zhejiang 315000, P.R. China

E-mail:wejklonnk@163.com

Key words: Lycium barbarum polysaccharide, palmitate, osteoblastic cells apoptosis, c-Jun NH2-teminal Kinase, endoplasmic reticulum stress for osteoporosis (OP), which can easily result in a fractures in the whole body $(1,2)$. In the recent years, the increasing global incidence of OP-assocaited morbidity and mortality have resulted in a severe losses (1-3). More and more researches have verified that obesity is closely associated with the occurrence and development of OP, which might be another risk factor that causes OP $(4,5)$. The content of serum free fatty acids in osteoblasts generally increases because of the accumulation of lipids and the reduction of utilization of fatty acids, which causes lipotoxicity in many cell types including osteoblasts (6-8). In the bone tissue, osteoblasts are the basis of the bone metabolism. The changes of in their functional status and relative amounts can cause bone metabolism abnormalities to ultimately progress to OP $(9,10)$. Therefore, the apoptosis of osteoblasts induced by high fat may be one of the important mechanisms for OP of osteoblasts. Palmitate (PA) is one of the most common saturated fats found in plants and animals, which can induce the apoptosis of osteoblasts due to its lipotoxicity $(11,12)$.

The endoplasmic reticulum (ER) is an important subcellular organelle involved in the synthesis of post-translational modifications, and proper folding of protein. Chemical stimulation can cause change its function in a process known as ER stress (ERS) (13). ERS is conducive to the restoration of cellular homeostasis and the mainteinance of cell survival. The continuous and high-intensity ERS can result in cell apoptosis. The up-regulation of GRP78 is considered to be the most sensitive signal in ERS (14). c-Jun NH2-teminal kinase (JNK) signaling pathway, as one of the important pathways in the mitogen-activated protein kinase pathway, plays an important role in the regulation of programmed cell death. The continuous and high-intensity ERS can activate the JNK signaling pathway by the formation of Irel/TRF2/ASK1 to induce cell apoptosis (15).

Lycium barbarum polysaccharide (LBP) is a kind of water-soluble polysaccharide extracted from Lycium barbarum, and it possesses important physiological functions in the human body. It consists of six monosaccharides, including arabinose, glucose 6-phosphate, galactose, mannose, xylose and rhamnose (16). Many studies showed that LBP has lipid-decreasing, hypoglycemic, anti-stress, antifatty-liver as well as, immunomodulatory effects $(16,17)$. At present, western medicine is still the main therapy for OP. Long-term medication has produced serious poisonous side effects, once 
has limited its drugs' efficacy better display. Compared to chemicals, Chinese herbal medicine has abundant resources and little side effects during the treatment of various diseases. This has been followed with interest $(18,19)$. Therefore, the aim of the present study was to investigate whether LBP treatment could attenuate apoptosis induced by PA, and to analyse the underlying molecular mechanisms.

\section{Materials and methods}

Cell culture and drug treatment. MC3T3-E1 cells were obtained from the Shanghai Cell Bank, Chinese Academy of Sciences (Shanghai, China), and maintained in $\alpha$-MEM medium supplemented with $10 \%$ fetal bovine serum (Gibco; Thermo Fisher Scientific, Inc., Waltham, MA, USA). They were cultured in a humid incubator at $37^{\circ} \mathrm{C}\left(95 \% \mathrm{O}_{2}\right.$ and $\left.5 \% \mathrm{CO}_{2}\right)$.

Cell viability. MC3T3-E1 cells were treated with various concentrations of PA $(0,100,200,300,400$ and $500 \mu \mathrm{g} / \mathrm{ml})$ for 6,12 and $24 \mathrm{~h}$. The cell viability was then assessed by the Cell Counting Kit (CCK)-8 kit (Tongren, Shanghai, China). Next, MC3T3-E1 cells were pre-treated with various concentrations of $\operatorname{LBP}(0,50,100,200,400$ and $800 \mu \mathrm{g} / \mathrm{ml})$ for $24 \mathrm{~h}$. Afterwards, $500 \mu \mathrm{g} / \mathrm{ml}$ of PA was added into the culture medium, and incubated for $6 \mathrm{~h}$. The cell viability was assessed by the CCK- 8 kit (Tongren). Briefly, $4 \times 10^{3}$ cells were seeded in each 96 -well plate, and further incubated for $24 \mathrm{~h}$. The CCK-8 reagent was added to each well $1 \mathrm{~h}$ before the endpoint of the incubation. The optical density (OD) $450 \mathrm{~nm}$ values in each well were determined by a microplate reader. Experiments were repeated at least three times and each time in triplicate. The no-treatment group was taken as control.

Flow cytometric analysis. The apoptotic rate was assayed with a flow cytometer using an Annexin V-FITC apoptosis detection kit (Nanjing KeyGen Biotech Co., Ltd., Nanjing, China) according to the manufacturer's instructions. Briefly, MC3T3-E1 cells were pre-treated with $500 \mu \mathrm{g} / \mathrm{ml}$ of PA for $6 \mathrm{~h}$, and various concentrations of $\operatorname{LBP}(0,50,100,200,400$ and $800 \mu \mathrm{g} / \mathrm{ml}$ ) were then added into the culture medium, and incubated for $24 \mathrm{~h}$. Then the cells were harvested, washed with ice-cold PBS, resuspended in $500 \mu \mathrm{l}$ of binding buffer, followed by addition of $5 \mu \mathrm{l}$ of Annexin V stock solution and incubation for $10 \mathrm{~min}$ at $4^{\circ} \mathrm{C}$. Propidium iodide (PI) $(5 \mu \mathrm{l})$ was added to the cells, and they were immediately analysed using a FACSCalibur flow cytometer (BD Biosciences, San Jose, CA, USA).

RT-PCR analysis. Total RNA was extracted from cultured MC3T3-E1 cells using the TRIzol reagent (Takara Biotechnology Co., Ltd., Dalian, China). Then the RNA was reversely transcribed into cDNA using the PrimeScript RT reagent kit with gDNA Eraser (Takara Biotechnology Co., Ltd.). PCR amplification was executed in an ABI 7500 Fast Thermocycler (Applied Biosystems, Foster City, CA, USA), using a SYBR-Green PCR kit (TransGen Biotech Co., Ltd., Beijing, China). The PCR cycles were $95^{\circ} \mathrm{C}$ for $10 \mathrm{~min}$, followed by 40 cycles at $95^{\circ} \mathrm{C}$ for $15 \mathrm{sec}$ and an annealing/extension step at $60^{\circ} \mathrm{C}$ for $45 \mathrm{sec}$. The primers were designed by Shanghai Sangon Company (Shanghai, China). The specific primer sequences for each gene were listed as the follows: 5'-AACGATATCGCGGGCCCGAA-3' and 5'-GGAGGTGCCTTGAGCTAATT-3' for Caspase-3 (product: 117 bp); 5'-GATCAGATCGGGAATTGCAA-3' and 5'-AGGTGAGGAATTGGCTCCTT-3' for Caspase-9 (product: 112 bp); 5'-ATCGCCAACGATCAGGGCAA-3' and 5'-GGGTTGGAGGTGAGCTGGTT-3' for GRP78 (product: 107 bp); 5'-TGGAGCTTGTTCCAGCCACT-3' and 5'-GCA GGTCCTCATACCAGGCT-3' for CHOP (product: 144 bp); 5'-ACCGTAACTGCCAGAGTCTGAA-3' and 5'-ACCTTG CAAGAGCCGACCAT-3' for Caspase-12 (product: $140 \mathrm{bp}$ ) and 5'-AGCTCACTGGCATGGCCTTC-3' and 5'-CGCCTG CTTCACCACCTTCT-3' for GAPDH (product: 116 bp). GAPDH was used to normalize gene expression. Relative expression levels were calculated using the $2^{-\Delta \Delta \mathrm{Cq}}$ method. All experiments were performed in triplicate.

Western blot analysis. After PA/LBP co-treatment, MC3T3-E1 cells were harvested and washed twice with PBS and lysed in ice-cold radio immunoprecipitation assay buffer (RIPA; Beyotime, Shanghai, China) with freshly added $0.01 \%$ protease inhibitor cocktail (Sigma, Shanghai, China) and incubated on ice for $30 \mathrm{~min}$. The cell lysis were s centrifuged at $13,000 \mathrm{x} \mathrm{g}$ for $10 \mathrm{~min}$ at $4^{\circ} \mathrm{C}$ and the supernatants (20-30 $\mu \mathrm{g}$ of protein) were separated on a $10 \%$ SDS-PAGE gel and transferred electrophoretically to a polyvinylidene fluoride membrane (Merck Millipore, Shanghai, China). The blots were blocked with $5 \%$ skim milk, followed by the incubation with the antibodies against Caspase-3, Caspase-9, GRP78, CHOP, Caspase-12, p-JNK, JNK and GAPDH (Beyotime). The blots were then incubated with goat anti-mouse or anti-rabbit secondary antibody (Beyotime) and visualized using enhanced chemiluminescence (ECL; Thermo Fisher Scientific, Inc., Shanghai, China).

Statistical analysis. In this study, all variables were evaluated using the SPSS 18.0 (SPSS, Inc., Chicago, IL, USA). Differences between numerical variables were calculated using the Student's t-test and the results are presented as the mean \pm standard deviation. One-way analysis of variance (ANOVA) followed by Dunnett's test was used for statistical analysis. All tests performed were two-sided. $\mathrm{P}<0.05$ was considered to indicate a statistically significant difference.

\section{Results}

Pre-treatment of LBP increased the cell viability of MC3T3-E1 cells with after treatment with PA. In order to identify the effect of PA on the proliferation of MC3T3-E1 cells, CCK-8 assay was employed for the cell viability analysis. As shown in Fig. 1A, the cells were treated with PA $(0,100,200,300,400$ and $500 \mu \mathrm{g} / \mathrm{ml}$ ) for 6,12 and $24 \mathrm{~h}, \mathrm{PA}$ inhibited the cell proliferation in a dose- and time-dependent manner. A concentration of PA over $300 \mu \mathrm{g} / \mathrm{ml}$ could obviously decrease the cell viability of MC3T3-E1 cells at 6, 12 and $24 \mathrm{~h}$. Therefore, $500 \mu \mathrm{g} / \mathrm{ml}$ of PA was determined as the concentration to be used for further investigations. MC3T3-E1 cells were pre-treated with various concentrations of $\operatorname{LBP}(0,50,100,200,400$ and $800 \mu \mathrm{g} / \mathrm{ml})$ for $24 \mathrm{~h}$. Afterwards, $500 \mu \mathrm{g} / \mathrm{ml}$ of PA was added into the culture medium and incubated for $6 \mathrm{~h}$. The CCK- 8 assay was then employed for the analysis of cell viability. As shown in 

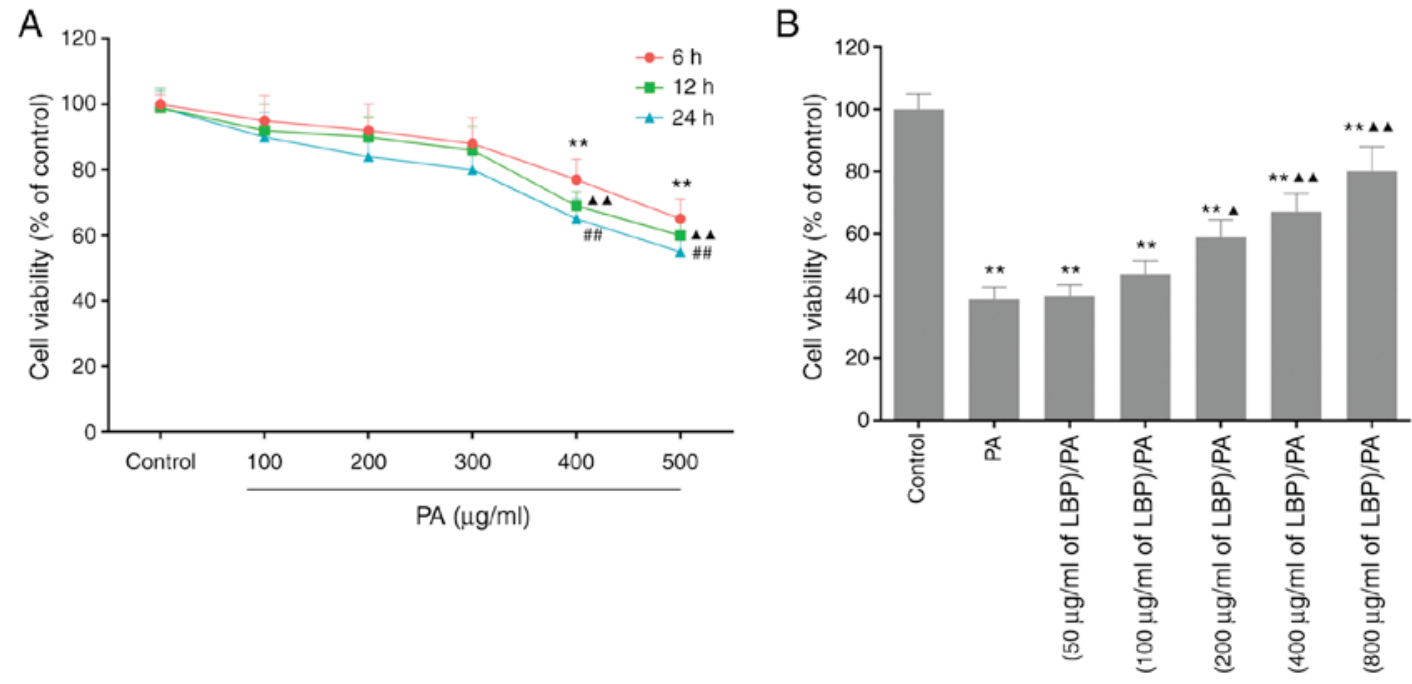

Figure 1. Effects of LBP on cell viability and cell apoptosis in MC3T3-E1 cells with PA pre-treatment. (A) Cells were treated with various concentrations of PA $(0,100,200,300,400$ and $500 \mu \mathrm{g} / \mathrm{ml})$ for 6,12 and $24 \mathrm{~h}$, and cell viability was detected by CCK-8 analysis. Data were presented as mean \pm standard deviation, $\mathrm{n}=3,{ }^{* *} \mathrm{P}<0.01$ vs. control in $6 \mathrm{~h} ;{ }^{\Delta \boldsymbol{\Delta}} \mathrm{P}<0.01$ vs. control in $12 \mathrm{~h}$; ${ }^{\# \#} \mathrm{P}<0.01$ vs. control in $24 \mathrm{~h}$. (B) Cells were pre-treated with various concentrations of LBP $(0$, $50,100,200,400$ and $800 \mu \mathrm{g} / \mathrm{ml}$ ) for $24 \mathrm{~h}, 500 \mu \mathrm{g} / \mathrm{ml}$ of PA was then added into the culture medium, and incubated for $6 \mathrm{~h}$, and cell viability was detected by CCK-8 analysis. Data were presented as mean \pm standard deviation, $\mathrm{n}=3,{ }^{* *} \mathrm{P}<0.01$ vs. control; ${ }^{\boldsymbol{\Lambda}} \mathrm{P}<0.01$ vs. PA. PA, palmitate; CCK-8, Cell Counting Kit-8.
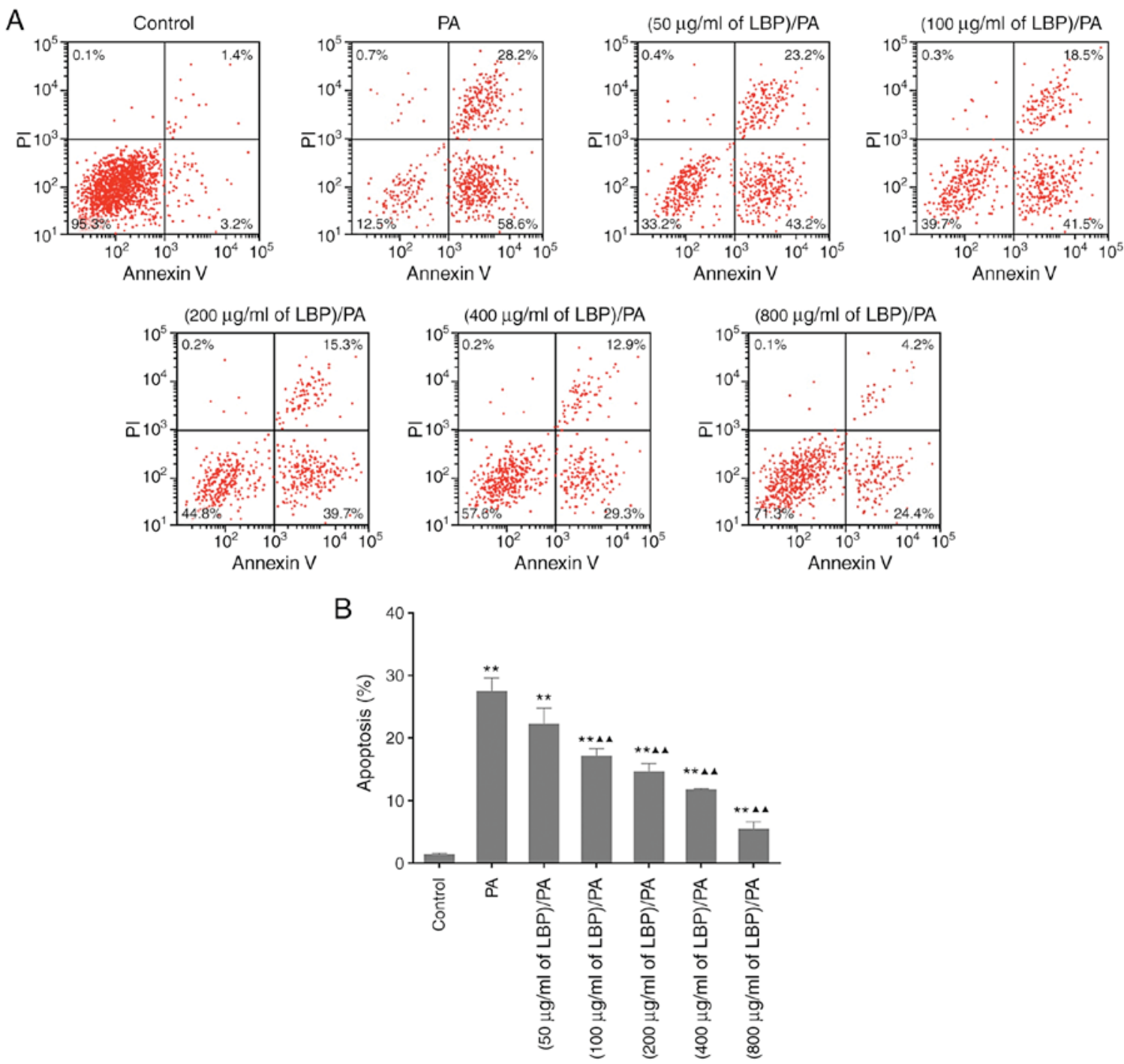

Figure 2. Effects of LBP on PA-induced apoptosis. (A) Cells were pre-treated with various concentrations of LBP (0, 50, $100,200,400$ and $800 \mu \mathrm{g} / \mathrm{ml})$ for $24 \mathrm{~h}$, $500 \mu \mathrm{g} / \mathrm{ml}$ of PA was then added into the culture medium, and incubated for $6 \mathrm{~h}$. The apoptosis rate was assayed with flow cytometry and (B) quantified. Data were presented as mean \pm standard deviation, $\mathrm{n}=3,{ }^{* *} \mathrm{P}<0.01$ vs. control; ${ }^{\wedge} \mathrm{P}<0.01$ vs. PA. LBP, Lycium barbarum polysaccharide; $\mathrm{PA}$, palmitate. 
A

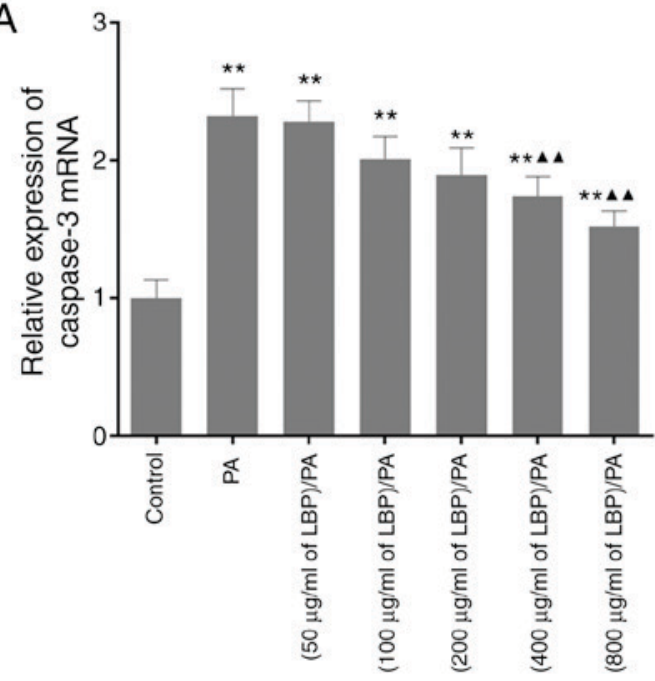

B

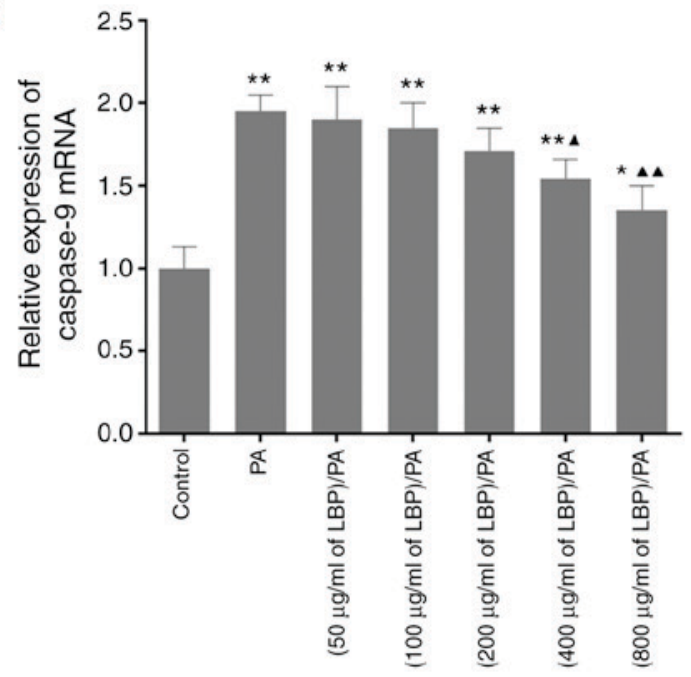

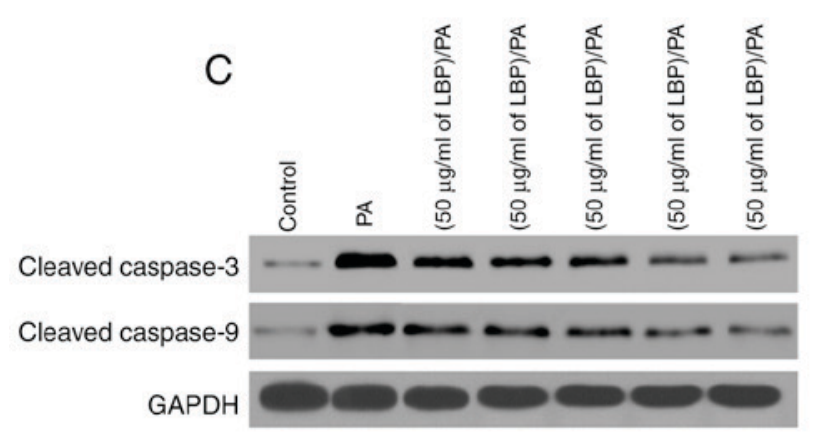

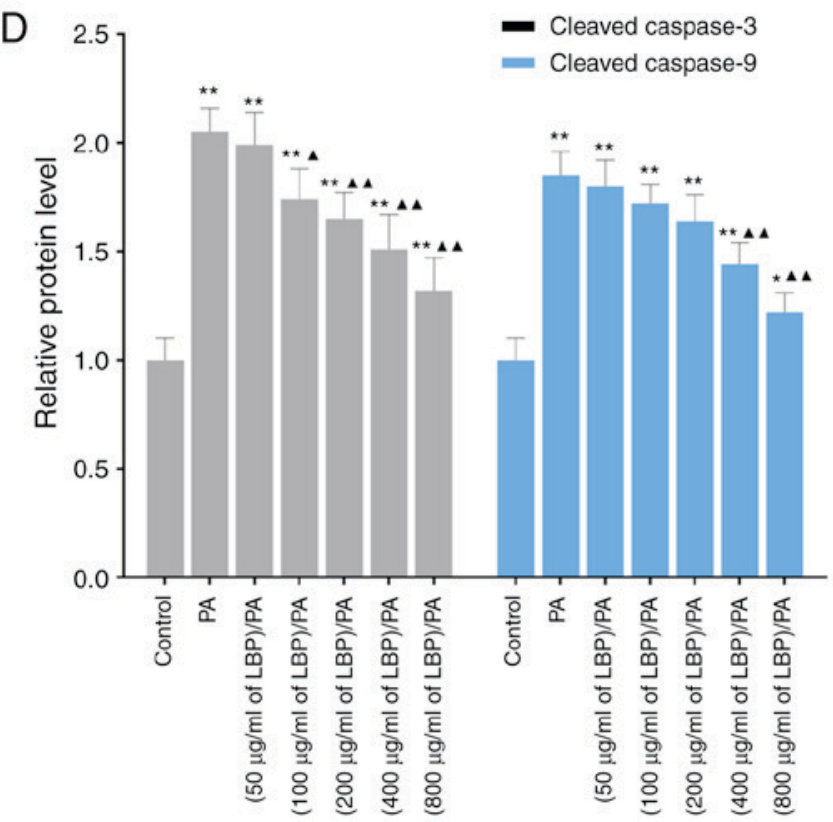

Figure 3. Effects of LBP on the expression levels of apoptosis-related genes. (A and B) Cells were pre-treated with various concentrations of LBP (0, 50, 100, 200,400 and $800 \mu \mathrm{g} / \mathrm{ml}$ ) for $24 \mathrm{~h}, 500 \mu \mathrm{g} / \mathrm{ml}$ of PA was then added into the culture medium, and incubated for $6 \mathrm{~h}$. The mRNA expression levels of Caspase-3/9 were detected by RT-PCR. (C and D) Cells were pre-treated with various concentrations of LBP $(0,50,100,200,400$ and $800 \mu \mathrm{g} / \mathrm{ml})$ for $24 \mathrm{~h}, 500 \mu \mathrm{g} / \mathrm{ml}$ of PA was then added into the culture medium, and incubated for $6 \mathrm{~h}$. The protein expression levels of clevaed-caspase-3/9 were detected by western blotting. Data were presented as mean \pm standard deviation, $\mathrm{n}=3,{ }^{*} \mathrm{P}<0.05$ and ${ }^{* *} \mathrm{P}<0.01$ vs. control; ${ }^{\mathbf{\Delta}} \mathrm{P}<0.05$ and ${ }^{\mathbf{\Delta}} \mathrm{P}<0.01$ vs. PA. LBP, Lycium barbarum polysaccharide; PA, palmitate.

Fig. 1B, LBP could promote the cell proliferation in a doseand time-dependent manner.

Pre-treatment of $L B P$ reduced the PA-induced apoptosis in MC3T3-E1 cells. PA showed cytotoxic effects in MC3T3-E1 cells. Therefore, we explored the protective effect of LBP on PA-treated MC3T3-E1 cells. As shown in Fig. 2A, $500 \mu \mathrm{g} / \mathrm{ml}$ of PA significantly increased cell apoptosis compared to the control group, while LBP could decrease PA-induced apoptosis in a dose dependent manner. Fig. 2B shows that the cell apoptosis rate of the control as well as PA, $(50 \mu \mathrm{g} / \mathrm{ml}$ of LBP)/PA, $(100 \mu \mathrm{g} / \mathrm{ml}$ of LBP)/PA, $(200 \mu \mathrm{g} / \mathrm{ml}$ of LBP)/PA, $(400 \mu \mathrm{g} / \mathrm{ml}$ of LBP)/PA, and $(800 \mu \mathrm{g} / \mathrm{ml}$ of LBP)/PA. PA resulted in an apoptosis rate of $27.5 \pm 2.12 \%$ compared to the control group of $1.40 \pm 0.15 \%$.
However, LBP decreased the apoptosis rate as $22.3 \pm 2.5 \%$ $(50 \mu \mathrm{g} / \mathrm{ml}), 17.2 \pm 1.12 \%(100 \mu \mathrm{g} / \mathrm{ml}), 14.70 \pm 1.2 \%(200 \mu \mathrm{g} / \mathrm{ml})$, $11.8 \pm 0.09 \%(400 \mu \mathrm{g} / \mathrm{ml})$, and $5.5 \pm 1.1 \%(800 \mu \mathrm{g} / \mathrm{ml})$. This shows that LBP decreases the PA-induced apoptosis in MC3T3-E1 cells. In addition, RT-PCR and Western blot analyses were used to detect the levels of apoptosis-related genes, including Caspase-3/9. We found that the expression levels of Caspase-3/9 were significantly up-regulated after PA treatment in MC3T3-E1 cells, and LBP could reduce the expression levels of Caspase-3/9 in MC3T3-E1 cells with PA treatment (Fig. 3)

LBP inhibits the expression of ERS-associated genes including GRP78, CHOP and Caspase-12 in MC3T3-E1 cells with PA pre-treatment. Consequently, we examined the 

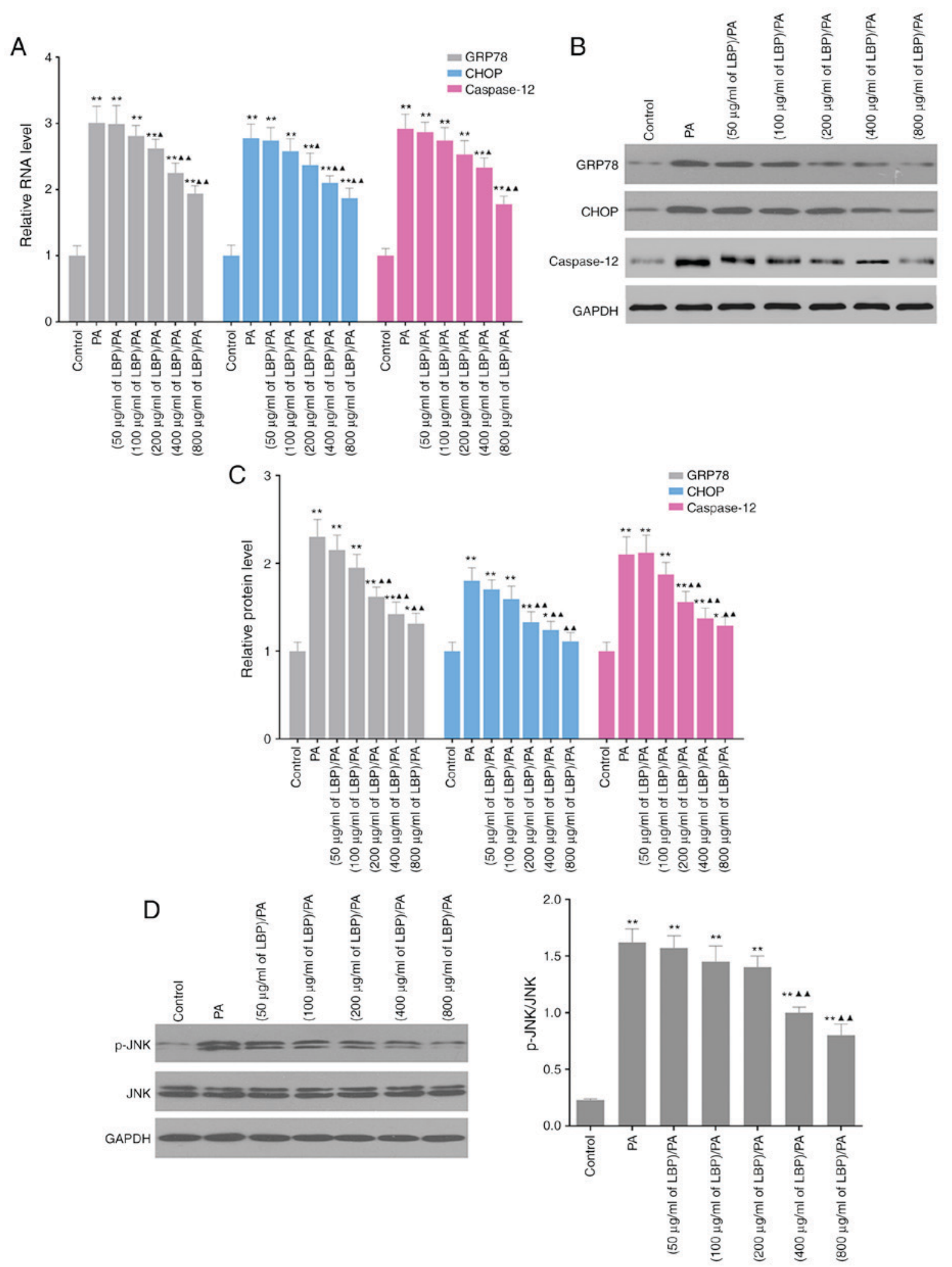

Figure 4. Effects of LBP on the expression levels of ERS-related genes and the activation of JNK signaling pathway in MC3T3-E1 cells with PA pre-treatment. (A-C) Cells were pre-treated with various concentrations of LBP $(0,50,100,200,400$ and $800 \mu \mathrm{g} / \mathrm{ml})$ for $24 \mathrm{~h}, 500 \mu \mathrm{g} / \mathrm{ml}$ of PA was then added into the culture medium, and incubated for $6 \mathrm{~h}$. The expression levels of GRP78, CHOP and Caspase-12 were detected by Western blot and RT-PCR. (D) Cells were pre-treated with various concentrations of $\operatorname{LBP}(0,50,100,200,400$ and $800 \mu \mathrm{g} / \mathrm{ml})$ for $24 \mathrm{~h}, 500 \mu \mathrm{g} / \mathrm{ml}$ of PA was then added into the culture medium, and incubated for $6 \mathrm{~h}$. The phosphorylation level of JNK protein was detected by western blotting. Data were presented as mean \pm standard deviation, $\mathrm{n}=3$, $\mathrm{P}<0.05$ and ${ }^{* *} \mathrm{P}<0.01$ vs. control; ${ }^{\mathbf{\Delta}} \mathrm{P}<0.05$ and ${ }^{\mathbf{\Delta}} \mathbf{P}<0.01$ vs. PA. LBP, Lycium barbarum polysaccharide; PA, palmitate; ERS, endoplasmic reticulum stress; JNK, c-Jun NH2-teminal kinase.

effects of LBP on the expression levels of GRP78, CHOP and Caspase-12 by RT-PCR and western blot analysis. As shown in Fig. 4A-C, the treatments of the cells with PA resulted in a steep decrease in the activation of GRP78, CHOP and 
Caspase-12, which caused ERS. Interestingly, the addition of LBP $(50,100,200,400$ and $800 \mu \mathrm{g} / \mathrm{ml})$ significantly and dose-dependently inhibited the PA-induced activation of GRP78, CHOP and Caspase-12. Collectively, these results indicate that LBP is a potent inhibitor of PA-induced apoptosis in osteoblastic cells.

LBP suppresses the activation of JNK signaling in MC3T3-E1 cells with PA pre-treatment. In a Western blot analysis, JNK expression was identified in MC3T3-E1 cells pre-treated with PA. Fig. 4D showed that JNK expression was increased by PA treatment. However, LBP could revise this increase. The treatment of the cells with LBP greatly suppressed the expression level of JNK. Therefore, co-incubation of the cells with LBP significantly inhibited the phosphorylation of JNK. Collectively, these results suggest that LBP could suppress the activation of the JNK pathway caused by the PA treatment.

\section{Discussion}

Normally, bone mechanical integrity is maintained by a dynamic balance between bone resorption by osteoclasts and bone formation by osteoblasts $(9,10)$. The decreased number and the dysfunction of osteoblasts as well as the increased activities and ratio of osteoclasts can result in balanced disturbances of the bone metabolism. When the bone remodelling is disturbed, this leads to OP $(5,9,10)$. Obesity means an over-deposition of fat due to a disequilibrium of the energy metabolism and a too much intake of calories $(4,5)$. Recent studies found that obesity could result in the loss of bone density, the thinning of bone tissue, the enhancement of bone fragility and the increased of the risk of bone fracture and many more (20). The establishment of an animal mode with hyperlipidaemia also confirmed that obesity caused by a high-fat diet could induce OP $(21,22)$. There reported that the increase of apoptosis induced by high fat in osteoblasts was one of the major causes for OP in obese patients $(7,11)$. In our results, PA could significantly suppress cell viability and increase cell apoptosis in MC3T3-E1 cells (Figs. 1 and 2). In addition, the expression levels of apoptosis-related genes were significantly decreased after LBP treatment (Fig. 3). The results were in accordance with other reports, and showed that PA could induce the apoptosis of osteoblasts in vitro.

Apoptosis is a programmed cell death regulated by genes in order to maintain homeostasis. The death-receptor, mitochondria and ERS are involved in cell apoptosis. Unfolded proteins accumulate during ERS and ER resident protein GRP78 protects cell via inhibiting protein synthesis and increasing protein degradation (23). However, continued, excessive or aberrant ERS can cause cell apoptosis through activation of the CHOP pathway, the Caspase- 12 pathway and the JNK pathway (13). In this study, the expression of GRP78, CHOP and Caspase-12 aas well as the phosphorylation level of JNK were significantly increased after PA treatment (Fig. 4). Some studies showed that Caspase-12 expression was detected during ERS, but Caspase-12 expression was not detected during the death-receptor and mitochondria apoptotic signaling pathways (24). Therefore, PA could significantly increase cell apoptosis caused by ERS via the activation of CHOP, Caspase-12 and JNK pathway. When we pretreated MC3T3-E1 cells with LBP, the apoptosis in osteoblasts was effectively inhibited (Fig. 1) in a dose dependent manner. The expression of GRP78, CHOP and Caspase-12 as well as the phosphorylation level of JNK were effectively decreased by co-incubation of LBP. It showed that LBP could significantly reduce the apoptosis of osteoblasts, which was depended on the concentration of interaction through inhibiting excessive or aberrant ERS.

In conclusion, PA could cause osteoblasts cells apoptosis, and LBP reduces PA-induced apoptosis in osteoblasts cells via inhibition of the activation of ERS caused by the JNK pathway.

\section{References}

1. Rachner TD, Khosla S and Hofbauer LC: Osteoporosis: Now and the future. Lancet 377: 1276-1287, 2011.

2. Ray NF, Chan JK, Thamer M and Melton LJ III: Medical expenditures for the treatment of osteoporotic fractures in the United States in 1995: Report from the National Osteoporosis Foundation. J Bone Miner Res 12: 24-35, 1997.

3. Ravn P, Cizza G, Bjarnason NH, Thompson D, Daley M, Wasnich RD, McClung M, Hosking D, Yates AJ and Christiansen C: Low body mass index is an important risk factor for low bone mass and increased bone loss in early postmenopausal women. Early postmenopausal intervention cohort (EPIC) study group. J Bone Miner Res 14: 1622-1627, 1999.

4. Aguirre L, Napoli N, Waters D, Qualls C, Villareal DT and Armamento-Villareal R: Increasing adiposity is associated with higher adipokine levels and lower bone mineral density in obese older adults. J Clin Endocrinol Metab 99: 3290-3297, 2014

5. Cohen A, Dempster DW, Recker RR, Lappe JM, Zhou H, Zwahlen A, Müller R, Zhao B, Guo X, Lang T, et al: Abdominal fat is associated with lower bone formation and inferior bone quality in healthy premenopausal women: A transiliac bone biopsy study. J Clin Endocrinol Metab 98: 2562-2572, 2013.

6. Arner P and Rydén M: Fatty Acids, Obesity and insulin resistance. Obes Facts 8: 147-155, 2015.

7. Elbaz A, Wu X, Rivas D, Gimble JM and Duque G: Inhibition of fatty acid biosynthesis prevents adipocyte lipotoxicity on human osteoblasts in vitro. J Cell Mol Med 14: 982-991, 2010.

8. Sharma S, Tandon VR, Mahajan S, Mahajan V and Mahajan A: Obesity: Friend or foe for osteoporosis. J Midlife Health 5: 6-9, 2014.

9. Kikuta S, Tanaka N, Kazama T, Kazama M, Kano K, Ryu J, Tokuhashi Y and Matsumoto T: Osteogenic effects of dedifferentiated fat cell transplantation in rabbit models of bone defect and ovariectomy-induced osteoporosis. Tissue Eng Part A 19: 1792-1802, 2013.

10. Lubkowska A, Dobek A, Mieszkowski J, Garczynski W and Chlubek D: Adiponectin as a biomarker of osteoporosis in postmenopausal women: Controversies. Dis Markers 2014: 975178, 2014.

11. Kim JE, Ahn MW, Baek SH, Lee IK, Kim YW, Kim JY, Dan JM and Park SY: AMPK activator, AICAR, inhibits palmitate-induced apoptosis in osteoblast. Bone 43: 394-404, 2008.

12. Martino L, Masini M, Novelli M, Beffy P, Bugliani M, Marselli L, Masiello P, Marchetti P and De Tata V: Palmitate activates autophagy in INS-1E $\beta$-cells and in isolated rat and human pancreatic islets. PLoS One 7: e36188, 2012.

13. Simon-Szabó L, Kokas M, Mandl J, Kéri G and Csala M: Metformin attenuates palmitate-induced endoplasmic reticulum stress, serine phosphorylation of IRS-1 and apoptosis in rat insulinoma cells. PLoS One 9: e97868, 2014.

14. Zhang H, Li H, Liu X and Bi J: Effect of caspase-9 inhibition on endoplasmic reticulum stress induced cortical neuronal injury in rats. Int J Clin Exp Med 6: 546-551, 2013.

15. 15. Wu H, Tang Q, Yang J, Ding J, Ye M and Dong W: Atorvastatin ameliorates myocardial ischemia/reperfusion injury through attenuation of endoplasmic reticulum stress-induced apoptosis. Int J Clin Exp Med 7: 4915-4923, 2014. 
16. Wu CX, Wang TF and Yu JQ: Lycium barbarum polysaccharide pretreatment attenuates cerebral ischemic reperfusion injury by inhibiting apoptosis in mice. Zhong Yao Cai 38: 1454-1459, 2015 (In Chinese).

17. Zhao R, Cai Y, Shao X and Ma B: Improving the activity of Lycium barbarum polysaccharide on sub-health mice. Food Funct 6: 2033-2040, 2015.

18. Bie M, Lv Y, Ren C, Xing F, Cui Q, Xiao J and So KF: Lycium barbarum polysaccharide improves bipolar pulse current-induced microglia cell injury through modulating autophagy. Cell Transplant 24: 419-428, 2015.

19. Li XM, Ma YL and Liu XJ: Effect of the Lycium barbarum polysaccharides on age-related oxidative stress in aged mice. J Ethnopharmacol 111: 504-511, 2007.

20. Mazziotti G, Bilezikian J, Canalis E, Cocchi D and Giustina A: New understanding and treatments for osteoporosis. Endocrine 41: 58-69, 2012.

21. Halade GV, Rahman MM, Williams PJ and Fernandes G: High fat diet-induced animal model of age-associated obesity and osteoporosis. J Nutr Biochem 21: 1162-1169, 2010.
22. Patsch JM, Kiefer FW, Varga P, Pail P, Rauner M, Stupphann D, Resch H, Moser D, Zysset PK, Stulnig TM and Pietschmann P: Increased bone resorption and impaired bone microarchitecture in short-term and extended high-fat diet-induced obesity. Metabolism 60: 243-249, 2011

23. Boot-Handford RP and Briggs MD: The unfolded protein response and its relevance to connective tissue diseases. Cell Tissue Res 339: 197-211, 2010.

24. Thuaud F, Bernard Y, Türkeri G, Dirr R, Aubert G, Cresteil T, Baguet A, Tomasetto C, Svitkin Y, Sonenberg N, et al: Synthetic analogue of rocaglaol displays a potent and selective cytotoxicity in cancer cells: Involvement of apoptosis inducing factor and caspase-12. J Med Chem 52: 5176-5187, 2009.

This work is licensed under a Creative Commons Attribution-NonCommercial-NoDerivatives 4.0 International (CC BY-NC-ND 4.0) License. 